\title{
Efek Penambahan Serat Kawat Bendrat terhadap Kuat Tekan dan Kuat Tarik Beton yang Dirawat melalui Metode Wet and Dry Curing
}

\author{
Nasruddin Junus*1 \\ ${ }^{1}$ Departemen Teknik Arsitektur, Fakultas Teknik, Universitas Hasanuddin \\ Jl. Poros Malino km.6, Bontomarannu, Gowa, Sulawesi Selatan, Indonesia, 92171 \\ *Email: nas_junus@yahoo.com
}

DOI: 10.25042/jpe.052017.06

\begin{abstract}
Abstrak
Penelitian ini bertujuan untuk menganalisis kemampuan serat kawat baja (bendrat) dalam meningkatkan sifat mekanis beton (kuat tekan dan kuat tarik belah). Jenis penelitian yang digunakan adalah kuantitatif dengan metode eksperimental yakni uji laboratorium dan analisis data metode komparatif dan regresi. Hasil penelitian menunjukkan serat dapat meningkatkan kuat tekan dan kuat tarik belah beton dari beton normal dengan perawatan basah lebih tinggi daripada perawatan kering. Pada dry curing meningkat pada komposisi 7,5\% sebesar $83,71 \%$ atau $18,5 \mathrm{MPa}$ (kuat tekan) dan $54,92 \%$ atau 2,2 $\mathrm{MPa}$ (kuat tarik belah). Dan pada wet curing meningkat sebesar 68,30\% atau $24 \mathrm{MPa}$ (kuat tekan) dan $35,38 \%$ atau 2,64 MPa (kuat tarik belah) pada komposisi 7,5\%.
\end{abstract}

\begin{abstract}
The Effect of Adding Annealed Wire Fiber to Compressive and Tensile Strength of Concrete Treated using Wet and Dry Curing Method. This study aims to analyze the ability of steel wire fiber (annealed) in improving the mechanical properties of concrete (compressive and tensile strength). The type of research used is quantitative with the experimental method of laboratory test and data analysis of comparative and regression methods. The research results showed that fiber can increase the compressive and tensile strength of concrete from normal concrete with higher wet treatment than dry treatment. In dry curing, it increased at $7.5 \%$ composition by $83.71 \%$ or $18.5 \mathrm{MPa}$ (compressive strength) and $54.92 \%$ or $2.2 \mathrm{MPa}$ (tensile strength). In wet curing, it increased by $68.30 \%$ or $24 \mathrm{MPa}$ (compressive strength) and $35.38 \%$ or $2.64 \mathrm{MPa}$ (tensile strength) at $7.5 \%$ composition.
\end{abstract}

Kata-kunci: beton, serat baja, kawat bendrat, kuat tekan, kuat tarik belah, slump beton

\section{Pendahuluan}

Dalam dunia konstruksi, pembangunan merupakan upaya yang dilakukan terus-menerus yang diarahkan pada peningkatan taraf hidup manusia dan kesejahteraan umum. Seiring dengan hal tersebut, dengan berkembangnya ilmu pengetahuan dan teknologi bangunan memacu adanya kreatifitas mulai dari peningkatan mutu, efisiensi dan produktivitas. Hal ini dapat dilihat dari kemajuan teknologi bangunan terutama dalam bidang konstruksi, struktur dan material bangunan. Salah satunya dengan ide menemukan, menggabungkan dan merekayasa suatu material yang telah banyak dilakukan dan diujikan dalam penelitian. Karakteristik arsitektur modern mengadopsi prinsip bahwa bahan dan fungsi sangatlah menentukan hasil dalam suatu struktur bangunan. Bahan-bahan yang digunakan dalam membangun gaya bangunan modern seperti beton, kaca, besi dan baja yang menambahkan pengetahuan bahwa gaya bangunan modern adalah sebuah penemuan baru dalam bidang revolusi industri.

Beton adalah salah satu bahan yang banyak dipakai dalam membangun karena memberikan kontribusi pada kekuatan bangunan, baik dari sisi daya tahan, kekuatan beton dan lain-lain. Namun beton juga memiliki kelemahan yaitu beton bersifat getas (tidak daktail) sehingga tidak mampu menahan tegangan tarik. Kuat tarik beton hanya berkisar 9\%-15\% dari kuat tekannya [1], sehingga beton memiliki keterbatasan dalam penggunaannya.

Para peneliti dari negara-negara maju seperti Amerika Serikat dan Inggris telah melakukan beberapa eksperimen dengan menambahkan bahan tambah yang bersifat kimiawi ataupun fisikal pada adukan beton. Salah satu alternatif 
bahan tambah yang digunakan bersifat fisikal yaitu serat. Penambahan serat ini dimaksudkan untuk memperbaiki sifat getas beton sehingga menjadi lebih daktail.

Dewasa ini jenis serat yang paling popular dipakai diluar negeri adalah steel fiber. Ide dasarnya yaitu menulangi (memberi tulangan pada beton) dengan serat baja yang disebarkan secara merata kedalam adukan beton dengan orientasi random. Menurut [2], serat baja memiliki modulus elastisitas paling tinggi diantara serat lainnya, yang akan meningkatkan penyerapan energi, mengontrol retak dan meningkatkan daktilitas beton. Namun serat baja masih sulit didapatkan karena harus didatangkan dari luar negeri dan harganya cukup mahal.

Berdasarkan pembahasan di atas, maka di lakukan penelitian untuk menganalisis pengaruh penambahan serat kawat bendrat pada campuran beton dengan tujuan untuk memperbaiki dan meningkatkan sifat-sifat mekanis beton yakni kuat tekan dan kuat tarik belah beton. Serat kawat baja (bendrat) dipilih karena disamping mempunyai faktor-faktor penguat beton, kawat bendrat juga lebih mudah didapat dan lebih ekonomis dibanding serat baja yang mencapai 10 kali lipat dari harga kawat bendrat.

Penelitian ini mengacu pada penelitian yang dilakukan sebelumnya yakni pada penelitian Suhendro (1991) dalam Ariatama Ananta [3] tentang penggunaan kawat biasa, kawat bendrat dan kawat baja dalam campuran beton. Hasilnya dapat disimpulkan dengan adanya serat pada beton dapat mencegah retak-retak rambut. Dengan penambahan serat pada adukan beton ternyata dapat meningkatkan ketahanan terhadap daktilitas, beban kejut (impact resistance) dan kuat desak. Tingkat perbaikannya tidak kalah dengan hasil-hasil yang dilaporkan diluar negeri dengan menambahkan steel fiber yang asli.

Tabel 1. Sifat-sifat berbagai macam kawat yang digunakan

\begin{tabular}{ccccc}
\hline No & Jenis Kawat & $\begin{array}{c}\text { Kuat } \\
\text { Tarik } \\
(\mathbf{M P a})\end{array}$ & $\begin{array}{c}\text { Perpanjangan } \\
\text { Saat Putus } \\
(\mathbf{\%})\end{array}$ & $\begin{array}{c}\text { Berat } \\
\text { Jenis }\end{array}$ \\
\hline 1 & Kawat baja & 230 & 10,5 & 7,77 \\
\hline 2 & Kawat bendrat & 38,5 & 5,5 & 6,68 \\
\hline 3 & Kawat biasa & 25 & 30 & 7,70 \\
\hline
\end{tabular}

Sumber :Suhendro dalam (Adi Saputra Hendri L, Tahun 2011)
Selain penambahan serat kawat bendrat untuk memperbaiki sifat kuat tarik lemah beton dan meningkatkan kuat tekan beton, perawatan juga perlu dilakukan agar kekuatan yang diinginkan pada beton dapat dicapai. Oleh karena itu, pada penelitian ini dilakukan 2 metode perawatan yaitu perwatan basah (wet) dan perawatan kering/tanpa dirawat (dry) untuk mengetahui perbandingan kekuatan masing-masing perawatannya. Dalam Paul Nugraha dan Antoni, Buku Teknologi Beton (2007) [2] mengatakan bahwa beton yang dirawat selama 7 hari akan lebih kuat sekitar 50\% daripada yang tidak dirawat.

\section{Metode Penelitian}

Penelitian yang bersifat eksperimental ini dilakukan di Workshop dan Laboratorium Material, Struktur dan Konstruksi Bangunan Jurusan Arsitektur Fakultas Teknik Universitas Hasanuddin Kampus Gowa. Adapun diagram alir penelitian ini terlihat pada Gambar 1 dibawah ini;

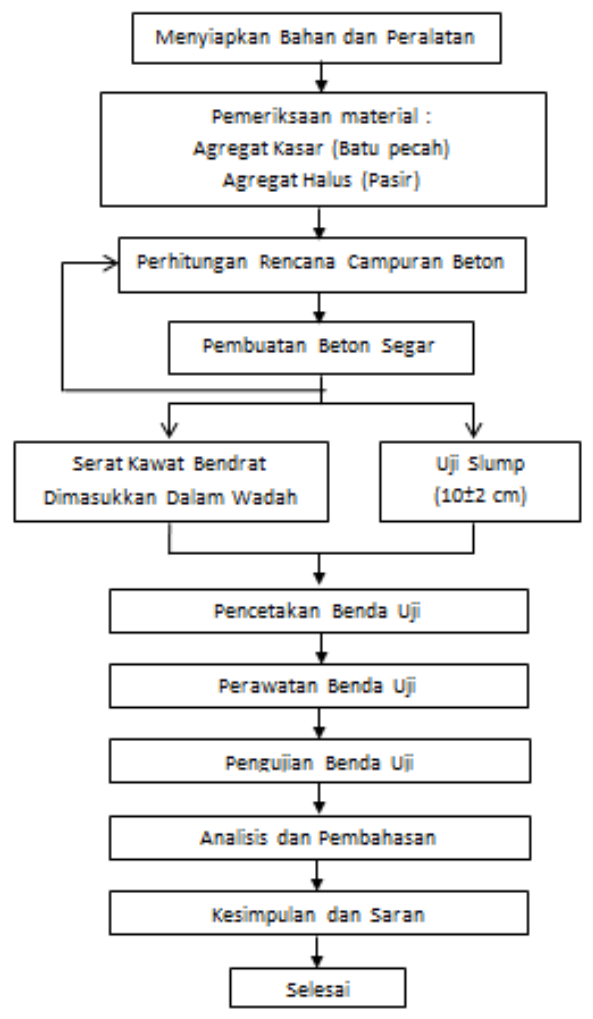

Gambar 1. Diagram alir penelitian

\subsection{Metode Pengumpulan Data}

Karena penelitian ini adalah eksperimental dimana data-data yang akan kita dapatkan diuji 
dalam lab, dengan acuan berdasarkan prosedur SNI pelaksanaan sebagai berikut :

- Berdasarkan SNI. T-15-1990-03, tentang tata cara pembuatan campuran beton normal. SNI ini dikenal sebagai metode perencanaan campuran DOE (Development of Environment), Inggris [4]

- Berdasarkan SNI 03-1972-1990, tentang metode pengujian slump beton [5]

- Berdasarkan SNI 03-1974-1990, tentang metode pengujian kuat tekan beton [6]

- Berdasarkan SNI 03-2491-2002 tentang metode pengujian kuat tarik belah beton [7]

\subsection{Metode Analisis Data}

Pada penelitian ini ada 4 variabel yang dijadikan dasar analisis, yaitu :

\subsubsection{Metode Pengujian}

Metode pengujian dalam rangka mencari nilai kekuatan dari sifat-sifat mekanis beton yakni kuat tekan dan kuat tarik belah beton dengan menggunakan universal testing machine, seperti yang terlihat pada Gambar 2.

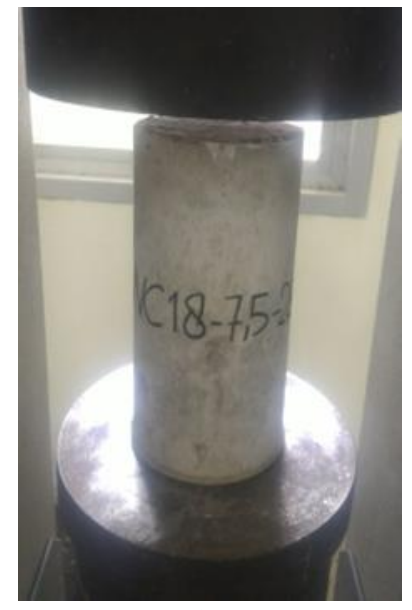

(a)

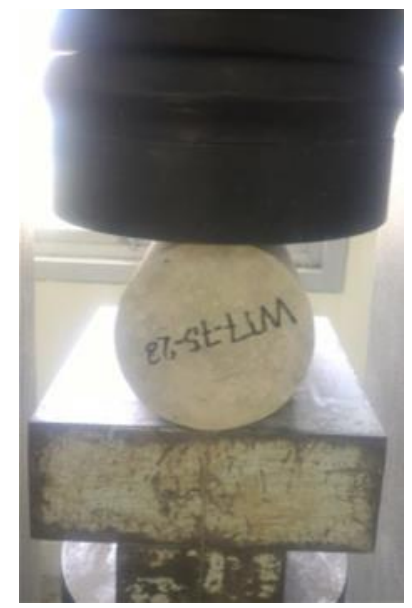

(b)
Gambar2. (a) Metode pengujian kuat tekan, (b) Pengujian kuat tarik belah

\subsubsection{Persentase serat kawat bendrat}

Terdapat 4 variasi persentase serat kawat bendrat berdiameter $0,8 \mathrm{~mm}$ yang dipotong dengan panjang $\pm 25 \mathrm{~mm}$ (aspek rasio 31,25) yakni $0 \%$ (reference concrete); 2.5\%; 5\% dan $7.5 \%$ dari berat semen.

\subsubsection{Umur beton}

Terdapat 3 variasi umur yang digunaan yakni umur 7, 14 dan 28 hari. Setiap kelompok umur tersebut terdiri dari 3 sampel benda uji silinder beton untuk setiap variasi persentase serat, metode perawatan dan metode pengujiannya.

\subsubsection{Curing (perawatan beton)}

Terdapat 2 cara perawatan yang digunakan yakni perawatan kering (dry curing) dan perawatan basah (wet curing). Khusus perawatan basah, dilakukan dalam curing room yang dilengkapi bak perendaman, bersuhu konstan $20^{\circ} \mathrm{C}$ dan kelembaban yang terjaga sekiar $70 \%$. Dan untuk perawatan kering benda uji diletakkan pada suhu ruangan bebas.

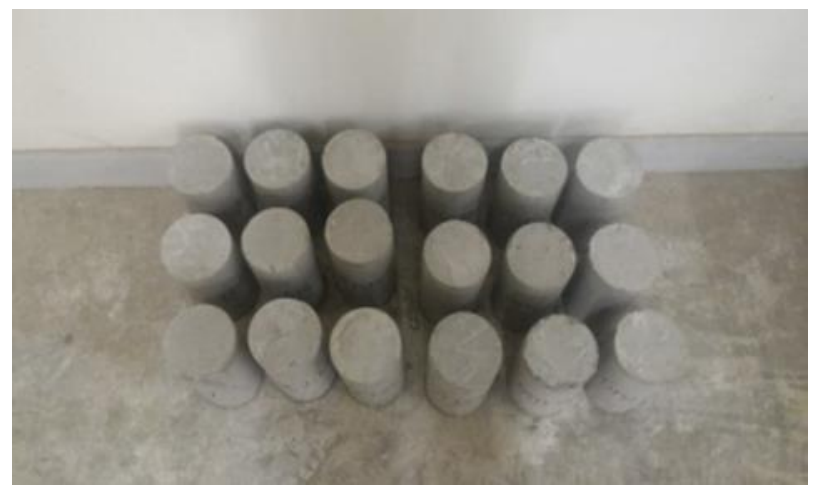

(a)

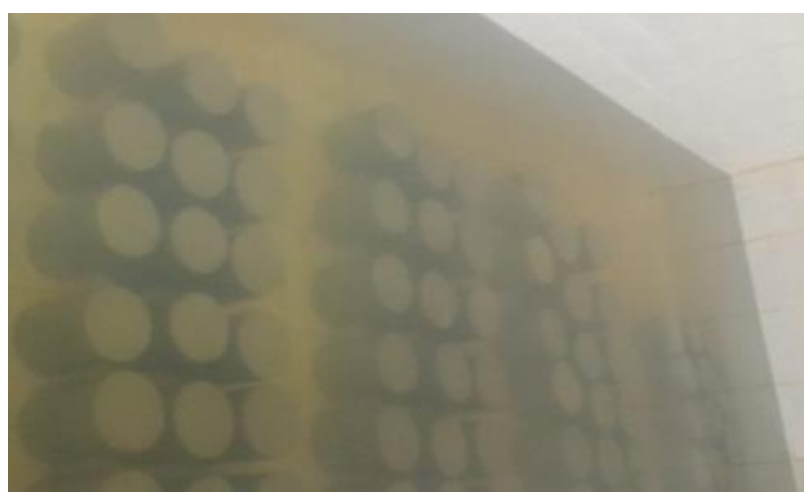

(b)

Gambar 3. (a) Metode perawatan kering, (b) metode perawatan basah

\section{Hasil dan Analisis}

Pada beton yang telah mengeras (hardness) dilakukan pengetesan kuat tekan (Compressive Strength) dan kuat tarik belah beton (Split Tensile Strength). Data yang didapatkan dari hasil pengujian ini ditabulasikan, kemudian diteliti 
pengaruh penambahan serat kawat bendrat terhadap kuat tekan beton dan kuat tarik belah beton serta dibandingkan dengan beton tanpa serat kawat bendrat. Hasil pengujian rekapitulasi dan grafik hasil kuat tekan dan kuat tarik belah dapat dilihat pada Tabel 2 dan Tabel 3 berikut.

Tabel 2. Rekapitulasi hasil kuat tekan beton

\begin{tabular}{ccccccccc}
\hline \multirow{2}{*}{$\begin{array}{c}\text { Umur } \\
\text { Beton }\end{array}$} & \multicolumn{9}{c}{ Kuat Tekan (Mpa) } \\
\cline { 2 - 9 } & $0 \%$ & $2,5 \%$ & $5 \%$ & $7,5 \%$ & $0 \%$ & $2,5 \%$ & $5 \%$ & $7,5 \%$ \\
\hline 7 & 8,9 & 9 & 12,56 & 18,33 & 8,3 & 8,43 & 10,02 & 17,72 \\
\hline 14 & 8,3 & 9,32 & 11,26 & 16,46 & 11,93 & 9,15 & 18,17 & 18,76 \\
\hline 28 & 10,07 & 10,25 & 13,66 & 18,5 & 14,26 & 12,35 & 20,5 & 24 \\
\hline
\end{tabular}

Tabel 3. Rekapitulasi hasil kuat tarik belah beton

\begin{tabular}{ccccccccc}
\hline & \multicolumn{8}{c}{ Kuat Tarik Belah (Mpa) } \\
\cline { 2 - 8 } Umur Beton & \multicolumn{6}{c}{ Wet } \\
\cline { 2 - 8 } & $0 \%$ & $2,5 \%$ & $5 \%$ & $7,5 \%$ & $0 \%$ & $2,5 \%$ & $5 \%$ & $7,5 \%$ \\
\hline 7 & 0,95 & 0,77 & 1,4 & 1,43 & 1,25 & 1,06 & 2,1 & 2,1 \\
\hline 14 & 1,35 & 1,2 & 1,88 & 2,67 & 1,83 & 1,67 & 2,57 & 2,43 \\
\hline 28 & 1,42 & 1,56 & 1,78 & 2,2 & 1,95 & 1,99 & 2,42 & 2,64 \\
\hline
\end{tabular}

Dapat dilihat dari Tabel 2, hasil pengujian umur 7 hari terjadi peningkatan kuat tekan beton dengan serat pada perawatan basah dan kering. Tetapi nilai kuat tekan beton dalam perawatan kering lebih tinggi daripada perawatan basah. Hasil uji ini tidak sesuai teori, dalam Paul Nugraha dan Antoni, Buku Teknologi Beton (2007) [2] mengatakan bahwa beton yang dirawat selama 7 hari akan lebih kuat sekitar 50\% daripada yang tidak dirawat. Hal ini dapat dipengaruhi oleh kondisi sampel pada perawatan basah. Pori-pori kapiler pada sampel perawatan basah terisi penuh oleh air yang menyebabkan air memberi desakkan lebih pada saat pengujian kuat tekan Gambar 4.
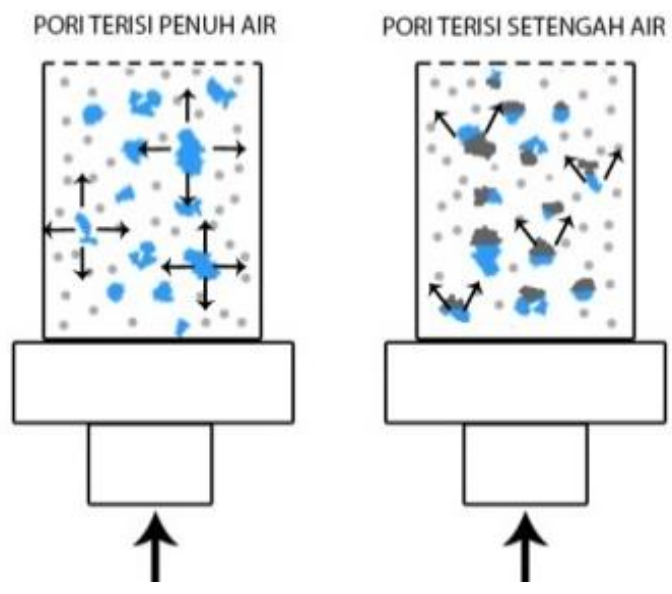

Gambar 4. Pengaruh keberadaan air dalam pori-pori beton

Pada hasil pengujian umur 14 hari benda uji pada perawatan basah, dengan komposisi serat
$2,5 \%$ mengalami penurunan kuat tekan beton sebesar $23,3 \%$ dari beton normal. Hal ini terjadi karena sampel-sampel 2,5\% berongga, sehingga menurunkan kekuatan beton. Rongga pada sampel akibat pemadatan (compacting) yang kurang baik.

Pada benda uji pada perawatan kering umur 28 hari, dengan komposisi serat 2,5\% mengalami penurunan kuat tarik belah beton sebesar $11,11 \%$ dari beton normal. Hal ini dapat terjadi karena proses ikatan matriks beton dan serat kawat bendrat belum sempurna.

Dapat dilihat dari Tabel 3, hasil pengujian umur 14 hari terjadi peningkatan kuat tarik belah beton dengan serat pada perawatan basah dan kering. Namun pada benda uji perawatan kering, dengan komposisi serat 2,5\% mengalami penurunan kuat tarik belah beton sebesar $11,11 \%$ dari beton normal. Hal ini dapat terjadi karena proses ikatan matriks beton dan serat kawat bendrat belum sempurna. Pada benda uji perawatan basah, dengan komposisi serat 2,5\% mengalami penurunan kuat tarik belah beton hanya berbeda $8,7 \%$ dari beton normal. Hal ini terjadi pada salah satu sampel serat 2,5\% hampir tidak terdapat kawat (gambar 5) serta beton 0\% terlihat lebih kuat ikatan betonnya, dilihat pada batu pecah dalam beton tersebut terbelah (Gambar 6). 


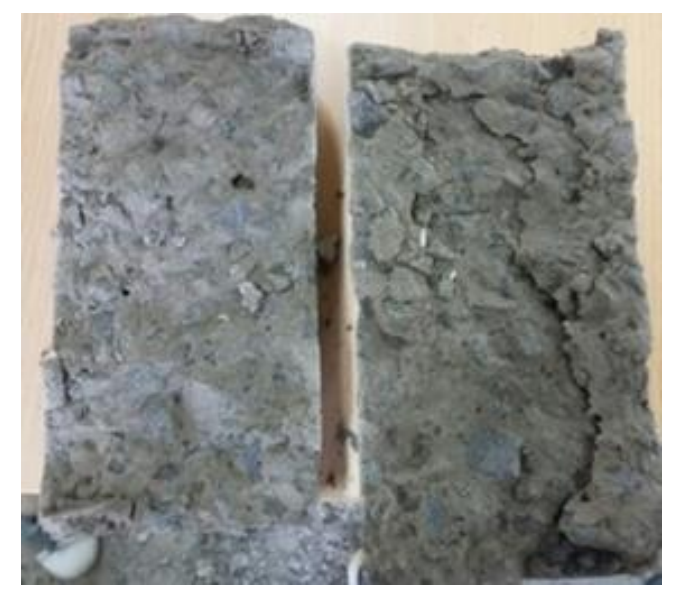

Gambar 5. Sampel 2,5\% wet curing hari ke 14 hampir tidak terdapat serat kawat bendrat pada pengujian kuat tarik belah

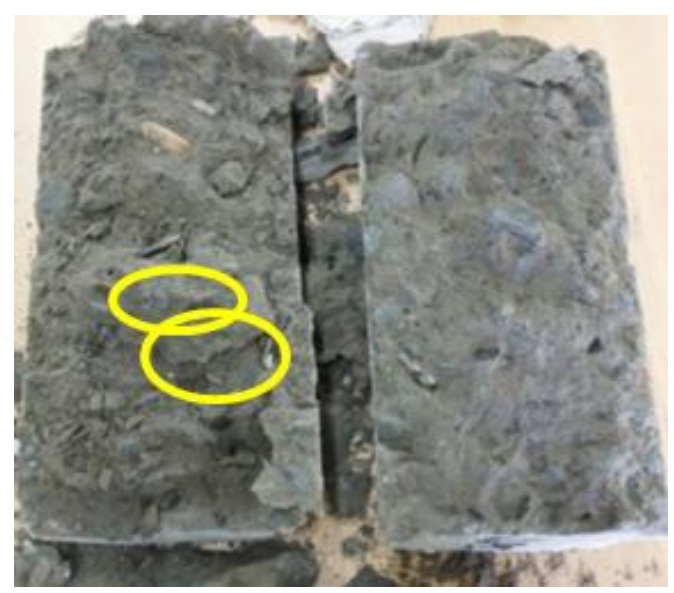

Gambar 6. Kondisi batu pecah terbelah pada sampel $0 \%$ wet curing hari ke 14 pada pengujian kuat tarik belah

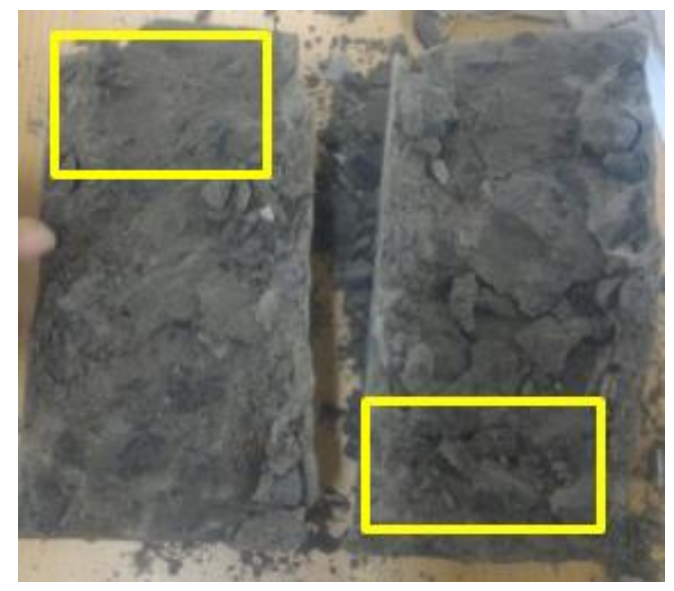

Gambar 7. Kondisi sampel 7,5\% wet curing dengan penyebaran yang tidak merata pada pengujian kuat tarik belah

\section{Nilai Optimum dan Minimum Kuat Tekan dan Kuat Tarik Belah Beton pada Jenis Perawatannya}

Untuk mengetahui nilai optimum dan nilai minimum dari data tabulasi sebelumnya pada variasi komposisi serat dengan kuat tekan dan kuat tarik belah beton dengan masing-masing perawatannya maka diolah menggunakan metode analisa regresi polynomial. Data yang digunakan untuk analisa regresi polynomial adalah hasil dari rata-rata kuat tekan dan kuat tarik belah umur 28 hari beton, karena berdasarkan SNI T-15-1990-03 umur 28 hari merupakan pada saat umur tersebut beton akan mengalami pengerasan secara sempurna hingga $100 \%$.

\subsection{Kuat Tekan Beton (Dry Curing)}

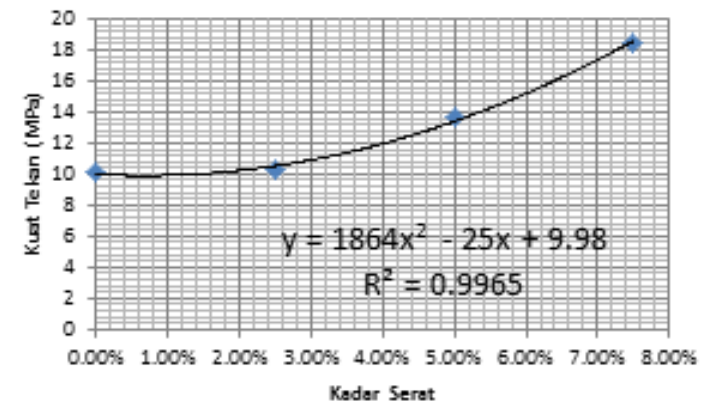

Gambar 7. Grafik analisa regresi polinomial kuat tekan beton umur 28 hari (dry curing)

Dari hasil analisa regresi tersebut, didapatkan nilai minimum $\mathrm{x}$ terjadi pada persentase serat $0,006 \%$. Pada persentase $0,006 \%$ mencapai nilai minimum y yaitu $9,8367 \mathrm{MPa}$

\subsection{Kuat Tekan Beton (Wet Curing)}

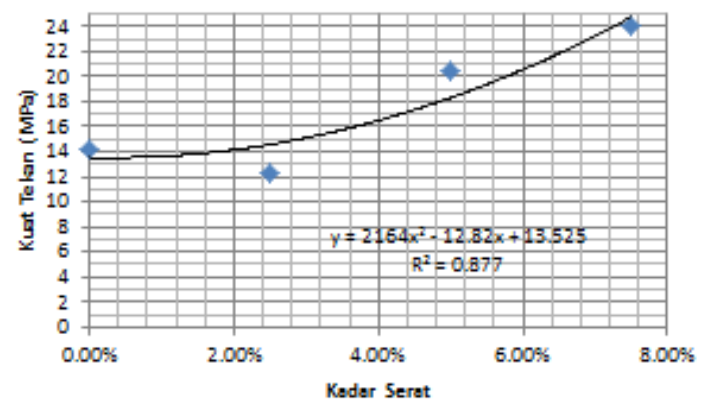

Gambar 8. Grafik analisa regresi polinomial kuat tekan beton umur 28 hari (wet curing)

Dari hasil analisa regresi tersebut, didapatkan nilai minimum $\mathrm{x}$ terjadi pada persentase serat $0,0029 \%$. Pada persentase $0,0029 \%$ mencapai 
nilai minimum y yaitu $13,5 \mathrm{MPa} \mathrm{MPa}$. Penurunan beton serat kawat bendrat yang cukup signifikan dari beton normal ini terjadi karena ikatan matriks beton dengan serat yang tidak sempurna.

\subsection{Kuat Tarik Belah Beton (Dry Curing)}

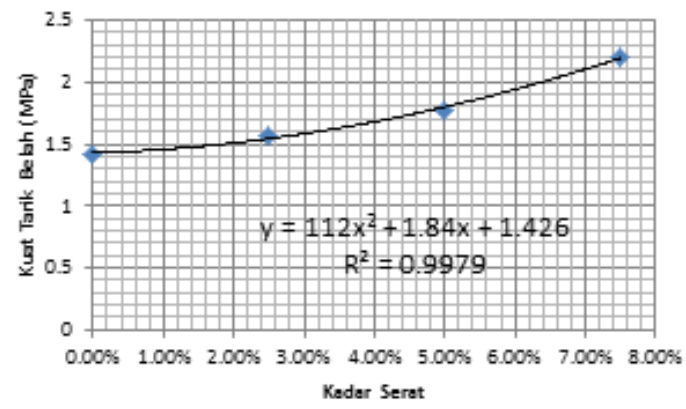

Gambar 9. Grafik analisa regresi polinomial kuat tarik belah beton umur 28 hari (dry curing)

Dari hasil analisa regresi tersebut, didapatkan nilai minimum $\mathrm{x}$ terjadi pada persentase serat $0,0082 \%$. Pada persentase $-0,0082 \%$. mencapai nilai minimum y yaitu $1,42 \mathrm{Mpa}$.

\subsection{Kuat Tarik Belah Beton (Wet Curing)}

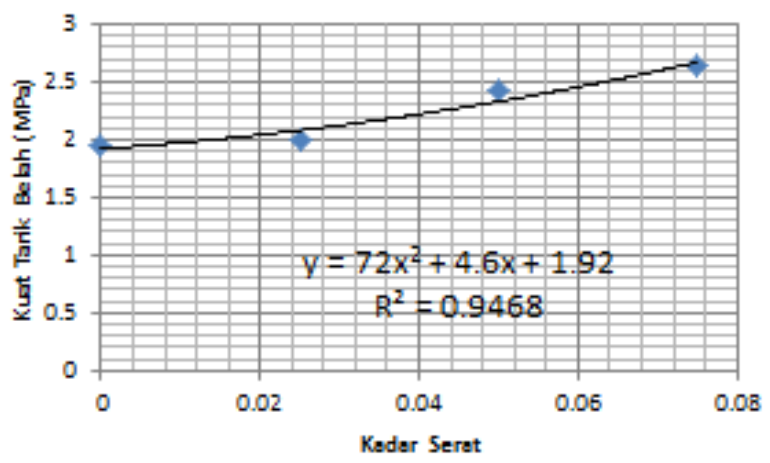

Gambar 10. Grafik analisa regresi polinomial kuat tarik belah beton umur 28 hari (wet curing)

Dari hasil analisa regresi tersebut, didapatkan nilai minimum $\mathrm{x}$ terjadi pada persentase serat $0,0013 \%$. Pada persentase $-0,0013 \%$. mencapai nilai minimum y yaitu $1,914 \mathrm{MPa}$.

Dapat disimpulkan berdasarkan hasil regresi polynomial diatas, kuat tekan dan kuat tarik belah pada jenis perawatannya telah membuktikan bahwa dengan adanya penambahan serat kawat bendrat panjang $\pm 2,5 \mathrm{~cm}$ pada campuran beton dapat meningkatkan kuat tekan dan kuat tarik belah beton. Pada kadar serat $7,5 \%$ terjadi peningkatan kuat tekan lebih dari $60 \%$ dan peningkatan kuat tarik hingga $50 \%$ daripada beton normal dan masih terjadi kemungkinan penambahan kekuatan tekan dan tarik belah beton dengan persentase serat yang lebih besar lagi. Sehingga tidak dapat dikatakan persentase serat 7,5\% sebagai nilai optimum kadar serat.

\section{Kesimpulan}

Dari hasil diatas maka dapat disimpulkan bahwa:

1) Pada perawatan kering penambahan serat kawat bendrat pada beton umur 28 hari dapat meningkatkan kuat tekan beton. Kuat tekan beton $0 \%$ (normal) $10,07 \mathrm{MPa}$, serat 2,5\% $10,25 \mathrm{MPa}$, serat 5\% 13,66 $\mathrm{MPa}$ dan serat 7,5\% 18,5 MPa. Dan pada perawatan basah penambahan serat kawat bendrat pada beton meningkat namun terjadi penurunan pada serat $2,5 \%$ karena serat yang sedikit, masingmasing kuat tekan dari $14,26 \mathrm{MPa}$ menjadi 12,35 $\mathrm{MPa}, 20,5 \mathrm{MPa}$ dan $24 \mathrm{MPa}$ (Mutu Beton K300). Pada perawatan kering penambahan serat kawat bendrat pada beton umur 28 hari dapat meningkatkan kuat tarik belah beton. Kuat tarik belah beton $0 \%$ (normal) 1,42 $\mathrm{MPa}$, serat 2,5\% 1,56 $\mathrm{MPa}$, serat 5\% 1,78 MPa dan serat 7,5\% 2,2 $\mathrm{MPa}$. Dan pada perawatan basah penambahan serat kawat bendrat pada beton meningkat masingmasing kuat tarik belah dari $1,95 \mathrm{MPa}$ menjadi 1,99 $\mathrm{MPa}, 2,42 \mathrm{MPa}$ dan 2,64 Mpa.

2) Berdasarkan hasil regresi polynomial, pada kadar serat lebih dari 7,5\% masih terjadi kemungkinan penambahan kekuatan tekan dan kuat tarik belah beton sehingga tidak dapat dikatakan sebagai nilai optimum kadar serat

\section{Ucapan Terimakasih}

Penulis ucapkan terima kasih kepada Pratiwi Mushar, ST, MT. dan Firda Yunisah Husni atas kontribusinya dalam penyelesaian penelitian ini.-

\section{Referensi}

[1] Dipohusodo, I.1994. Struktur Beton Bertulang berdasarkan SK-SNI-T-15-1991-03 Department Pekerjaan Umum RI. PT. Gramedia Pustaka Utama : Jakarta

[2] Nugraha, Paul dan Antoni. 2007. Teknologi Beton dari Material,Pembuatan, ke Beton Kinerja Tinggi. Yogyakarta: CV. Andi Offset

[3] Ariatama, A., 2007, Pengaruh Pemakaian Serat Kawat Berkait Pada Kekuatan Beton Mutu Tinggi Berdasarkan 
Optimasi Diameter Serat, Thesis, Program Pasca Sarjana Universitas Diponegoro, Semarang

[4] SNI. T-15-1990-03, tentang tata cara pembuatan campuran beton normal. SNI ini dikenal sebagai metode perencanaan campuran DOE (Development of Environment), Inggris

[5] SNI 03-1972-1990. Metode Pengujian Slump Beton. Badan Standarisasi Nasional

[6] SNI 03-1974-1990. Metode Pengujian Kuat Tekan Beton. Badan Standarisasi Nasional.

[7] SNI 03-2491-2002 Mmetode Pengujian Kuat Tarik Belah Beton Standarisasi Nasional. 